\title{
Semantic context of professional identity crisis experience by teachers
}

\author{
Nadezhda O. Sadovnikova - Tamara B. Sergeeva - Irina V. Deviatovskaja - \\ Svetlana S. Kotova - Alexander A. Shashmurin
}

\section{DOI: 10.18355/XL.2017.10.04.14}

\begin{abstract}
The topicality of the problem under research is predetermined by the need of psychology and pedagogy for the study of the phenomenology of professional identity crisis, the process of its experience by school teachers as well as for the development of the system of psychological and pedagogical support of teachers' professional development in the situation of permanent changes in the education system. The objective of the study is to reveal the content of the professional identity crisis, to describe its main features and analyze the semantic context of its experience by teachers. The principal methods of study of this problem are the phenomenological method, tests to identify the semantic context of the process of the professional identity crisis experience by teachers. The results of the study broaden the understanding of the phenomenon of professional identity crisis and its experience, the content of professional crisis and the phenomenology of professional development of teachers. The materials of the article may be useful for psychologists when designing programs of psychological support of teachers' professional development.

Key words: professional identity crisis, experience, sense and value sphere, phenomenological analysis
\end{abstract}

\section{Introduction}

The problem of crisis and crisis situations currently remains relevant for psychology and for society as a whole. Permanent changes in many public institutions, economic instability, globalization processes determine not only the increase of social tension, but also the growth of the sense of personal insecurity and instability experienced by modern man (Zeer, 2013; Kong, Kayumova \& Zakirova, 2017; Levina et al., 2017). The inability to satisfy one's own needs, the lack of opportunity to fulfill oneself in the family, in the profession and in life in general leads to crisis situations, forcing individuals to find ways out of them which are not always constructive.

The study of the category of crisis has particular importance in the context of pedagogical activities. The concept of modernization of Russian education formulates one of the main objectives of educational policy as the development of education in accordance with the current and future needs of the individual, society and the state and the provision of its quality while maintaining its fundamental nature. One of the ways of solving this task is to ensure the psychological safety of the educational process by improving the psychological well-being of teachers among other things. The ability of teachers to be permanently self-determined, to build themselves as professionals, to plan new trajectories of professional development and to overcome the psychological barriers of this process acquires special significance in the context of changes in the educational paradigm, introduction of Federal State Education Standards (FSES), changes in the approaches to the organization of the educational process (Asadullin, Frolov, 2017; Benin \& Frolov, 2014; Rensh, Kosyakova, Agafonova, 2016; Gafurov, Valeeva, 2017; Masalimova et al., 2017; Gorbunova, Sabirova, 2017; Luchinina, Yunusova, 2017; Khrulyova, Sakhieva, 2017). 
However, research shows that a significant number of teachers have difficulty in adapting to the rapidly changing socio-economic and occupational conditions. The unreadiness of teachers to reconsider their own role in the modern educational process and their inability to resolve professional difficulties (including external and internal conflicts, crises, stress, etc.) can be the cause for serious sociopsychological problems: from the increase in internal dissatisfaction to the growth of social confrontation and aggression. Dissatisfaction with the job, internal conflicts, the feeling of loss of sense of labour, lack of career prospects in some cases become factors that put up a barrier to the professional development of the teacher, and lead to the teacher's experiencing a professional identity crisis.

The notion "professional crisis" is firmly established in the Russian psychological science. The existence of professional development crises is described by such authors as Mogilevkin (2007), Zeer (2009), Povarenkov (2002), Pryazhnikov and Pryazhnikova (2005), and others.

Thus, Zeer and Symanyuk (2005) define professional development crises as short periods (up to one year) of the cardinal restructuring of the professional identity, activity and behavior of individuals, the change of the vector of their professional development. Crises lead to the shift towards new goals, to the correction and revision of the socio-professional position, prepare for the change of the ways of activity implementation, lead to the change in the relationships with other people, and in some cases to the career change (Zeer, Symanyuk, 2005).

According to Povarenkov (2002), for a professional the crisis (exemplified by the author as promotion or demotion, dismissal) results in emotional stress, the need for correction of self-evaluation.

Pryazhnikov and Pryazhnikova (2005) note that in the process of professionalization of the individual there arises a career crisis characterized by the dissatisfaction with oneself and one's own occupational status; revision of the selfconcept associated with the re-comprehension of oneself and one's place in the world. While experiencing this crisis the individual develops a new dominant of professional values, when some workers "suddenly" discover new meanings in the content and process of labour (instead of the old meanings which are often external in relation to labour) (Pryazhnikov, Pryazhnikova, 2005).

In his research Mogilevkin (2007) examines the crisis of the career development of the individual. In the course of the crisis, according to the author, there takes place an inevitable clash of old and new priorities, strategies, values and attitudes in the professional growth and career advancement.

Despite the fact that the works of many researchers dealing with issues of professionalization and professional development examine the category "professional crisis", however in all of them the content of professional crisis is analyzed in the context of stages of personal development in the profession. Yet, in our study we shall deal with the professional identity crisis.

The professional identity crisis is a prolonged unbalanced state of the subject of labour which is caused by the dissonance in the sense and value sphere of the individual and which actualizes the experience process that predetermines the further trajectory of the personal development in the profession and it either provides a transition to the next stage of professional formation, or it leads to the stagnation of the teacher, his/her professional degradation (Rensh, Kosyakova, Agafonova, 2016; Sadovnikova, 2016; Sadovnikova et al., 2016; Ke, Borakova, Valiullina, 2017; Zheltukhina et al., 2017).

The crisis affects the sphere of professional orientation of the individual: motivation, needs, values, meanings; it "makes" the individual construct the boundaries of one's own sense and value sphere, it actualizes the experience process. The key features of the process of experiencing the professional identity crisis are: 1) localization in space and time; 2) instability of images and thoughts of oneself as of a 
professional, loss of professional identity; 3) unclear time frames of career prospects, or their absence, and as a result, actualization of the need to choose the further professional life scenario; 4) actualization of life meaning experiences revealed in the low desire for self-development, self-affirmation, self-realization, in the sense of one's own irrelevance and incompetence; 5) the presence of persistent affective reactions, and stress (Sadovnikova, 2014).

The occurrence of the professional identity crisis is characterized by the lack of confidence in one's own abilities, disagreement with oneself, comprehension of the need to reassess oneself, uncertainty of life goals, lack of understanding of how to live, loss of the sense of the new, failure to keep pace with life, etc. The professional identity crisis can be said to be a situation of the "impossibility" to implement the internal career plan, a situation when a person is given a "problem of meaning" that needs solving (Sadovnikova, 2009).

With all the variety of studies of professional crises to date, there is still insufficient empirical data that reveal the semantic context of the professional identity crisis of a teacher and the specificity of the sense of experiencing a crisis.

\section{Review of Literature}

The earliest treatment of the category of crisis in psychology can be found in the works of such psychologists as A. Adler (1926), S. Freud (1917). The works of these authors describe crisis situations as states that accompany the development and formation of the personality. Later the categories "crisis" and "crisis situations" began to be explored through the prism of traumatic and stressful events.

The first studies of crisis problems in the context of traumatic situations were conducted by Lindemann (1944). In his research the crisis is seen as a state arising due to the impact of psychologically traumatic events on a person (Lindemann, 1944).

According to Caplan (1964), the crisis is a period of imbalance which is time-limited, accompanied by unpleasant psychic and physical feelings (sensation), sometimes it exhausts greatly the ability of the individual to overcome problems or to cope with the situation competently. Mental imbalance occurs when an individual is faced with an important life problem which cannot be avoided and cannot be solved in a short period of time in the normal way using the mechanisms of response regulation that are currently available (Caplan, 1964).

In the works of Caplan (1964) and Lindemann (1944) the category of crisis is regarded as a state of imbalance.

In some cases the category "crisis" is studied in the context of the course of life of the individual. For example, life crises were the subject of study of such psychologists as Bühler (1933), Lievegoed (1994), Erikson (1963), Sheehy (1999) and others. Dividing the human life into periods, stages and drawing attention to the difficulties of the transition from one stage to another, the researchers emphasized that the crisis is a turning point in a person's life.

As noted by Erikson (1963), each psychosocial stage is accompanied by a crisis - a turning point in the life of the individual, which arises as a consequence of achieving a certain level of psychological maturity and social requirements imposed on the individual at this stage.

Sheehy (1999) regards the crisis as a crucial point and says that during the transitional moments the way of life undergoes abrupt changes in four dimensions: the inner feeling toward others; a sense of safety and danger; perception of time - we have enough time, or we begin to feel the lack of time; a sense of physical decline.

Fillip and Aymanns (2010) describe life crises as time-limited situations, characterized by imbalance between external and internal planes of human existence that cannot be resolved with the existing resources of the individual.

XLinguae, Volume 10, Issue 4, October 2017, ISSN 1337-8384, eISSN 2453-711X 
In the existential-humanistic studies of Assagioli (1997), Maslow (1971), Grof and Halifax (1996) and others, the crisis is seen as an organic part of the process of personality development. So, for example, Grof and Halifax (1996) note that a crisis situation can be difficult, but it has a great evolutionary and healing potential. Being a difficult situation of natural development the crisis may lead to the healing of various emotional and psychosomatic disorders, to favorable changes in personality, to the solution of important problems of life.

In the works by Ulich et al., (1985) the crisis is spoken about when it affects central areas of life activity. The crisis can be provoked by comprehensive and serious depressing changes arising from the inside and the outside, which the individual should cope with to regain the overall positive mental state.

Existential crises are spoken about in the works by James and Gilliland (2005), Olson (2013). The authors note that existential crises are related to the processes of self-actualization of the individual. They occur when a person is aware of the fact that the goals he set earlier are unachievable (Olson, 2013).

So, foreign researchers consider the category of crisis as a phenomenon of the individual human life in the context of the individual's experiencing psychologically traumatic situations. The main aspect of the crisis is the lack of balance in the system "existence-personality". The crisis experience results in the spiritual enrichment of the individual.

The Russian psychological science has studied the problem of crisis for a long time. Most of the research works were conducted in the context of studying the problems of the formation and development of the personality in childhood, as well as in the context of the course of life of the individual. In these works the crisis is regarded primarily as a standard phenomenon which is necessary for the progressive development of the personality.

Vygotsky (1927) was the first to study crises of development in Russian psychology. His merit is that he proposed a new model for explaining the psychological meaning and mechanisms of age crises of development. The crisis in his concept is a natural and necessary link in the development. The function of the crisis is the resolution of contradictions arising in the course of the psychological development of the child (the discrepancy between the old social situation of development and the level of achievement of the child). In the periods of crises of development there occurs a profound transformation of the social situation of development, giving a new impetus and direction to the mental development of the child.

Soldatova (2007), focuses on standard crises of adulthood and shows that the notion of crisis indicates different levels of the same reality, which explains its varied, and above all, incomplete interpretation. The crisis period is determined by Soldatova (2007) as an inevitable transition from one age stage to the next one, associated with the transformation of the social situation of development, with the destruction of the old system of relations, and then with the discovery, exploration and acceptance of the new one.

As noted by Martsinkovskaya (2002), psychological crises proper are first of all crises of development, or ontogenetic crises that are a natural part of the process of psychological development. These crises may be triggered both by internal variables (reflection, self-actualization needs, differentiation of the self-concept, etc.), and by external ones, related to the drastic changes in the social situation, the transformation of the status position, the loss of loved ones, especially if they have been objects of identification (Martsinkovskaya, 2002). The essence of the crisis is associated with the qualitative transition of a person to a new stage, in which one discovers a new world picture, new meanings and relationships with people, and revises many of the values. 
Vasilyuk (1984) understands the crisis as a critical moment and a turning point in the course of life, accompanied by the internal emotional imbalance caused by a threat from external circumstances. The concept of crisis experience developed by Vasilyuk (1984) includes the description of the mechanism of value experience. The researcher says that in a crisis situation, whatever its exact nature, there is discord between consciousness and existence. Consciousness cannot take existence for reality, hence consciousness cannot provide it with meaning and guide it. This creates a situation of loss of meaning, which can be coped with due to value-semantic reconstructions.

Yurieva (1998) considers the crisis as an unsuccessful attempt to overcome threatening problems or situations. According to the author the crisis is a temporary disintegration of personality, caused by the situation or the inner state. This disintegration can have a positive or negative outcome. Negative disintegration is accompanied by destructive changes of personality. Positive disintegration leads to the enrichment of personality and to the transition of personality to a new level of integrity.

Malkina-Pykh (2004) defines the crisis as a situation of impossibility of further existence in the previous status, i.e. a situation in which the subject is faced with the impossibility of implementing the internal necessities of his/her life (motivations, aspirations, values) by conventional means.

Prokhorov (2004) considers the crisis as an imbalanced situation which in everyday life can be caused by the rupture of a customary system of relationships, the loss of significant values, the impossibility of achieving the goals, the loss of a loved one, etc. All this is accompanied by negative emotional experiences, the inability to assess the real situation and find a rational solution (Prokhorov, Chernov, Yusupov, 2017).

One of the areas of research of crises and crisis situations in the context of the course of life is the study of crises of professional development (formation). The existence of such kind of crises is indicated by Antsyferova (1981), Klimov (1996), Markova (1996), Fonarev (1997), Mitina (2002), Pryazhnikov and Pryazhnikova (2005), Zeer (2009, 2013), Symanyuk and Deviatovskaja (2015).

For example, Antsyferova (1981) in her works mentions critical and sensitive periods in the process of implementing a separate specific activity.

In the work of Markova (1996) it is noted that the crisis of professional development can occur when the old in the professional labour no longer satisfies, and the new has yet to be found or when the creative findings of the worker encounter resistance in the professional environment. As noted by the author, at moments of crisis of the development of the personality the mechanism of modification of the sense and value sphere of the individual is activated.

The existence of crises of professional formation is pointed out also by Povarenkov (2002). According to the researcher, in a crisis situation a professional experiences emotional stress, there arises the need for the correction of selfevaluation.

Pryazhnikov and Pryazhnikova (2005) note that in a crisis situation the individual develops a new dominant of professional values, when some workers "suddenly" discover new meanings in the content and process of labour (instead of the old meanings which are often external in relation to labour).

Mogilevkin (2007) examines the crisis of the career development of the individual. In the course of the crisis, according to the author, there takes place an inevitable clash of old and new priorities, strategies, values and attitudes in the professional growth and career advancement.

XLinguae, Volume 10, Issue 4, October 2017, ISSN 1337-8384, eISSN 2453-711X 
Zeer $(2009,2013)$ defines professional development crises as "short periods (up to one year) of the cardinal restructuring of the professional identity, activity and behavior of individuals, the change of the vector of their professional development".

On the basis of the analysis of the research works presented above, we can conclude that the phenomenology of crisis is revealed by such categories as "experience", "loss of meaning", "conflict of values", "deadaptation", "transformation of life plans", "lower level of life comprehension", etc. Many authors, both foreign and Russian ones, note that in a crisis situation there occurs reconsideration of the situation, reassessment of values.

As the professional identity crisis is a crisis situation accompanied by the modification of the sense sphere of the individual, it is important to reveal the features of sense transformation in order to have a possibility to provide more effective psychological support for teachers experiencing a crisis. At the same time as of today no one has researched in detail the semantic context specific to the professional identity crisis (Sadovnikova et al., 2016).

The occurrence of the professional identity crisis is associated with the dissonance in the sense and value sphere of the individual caused by the disparity of relationships in the "personality-profession" system. This condition is characterized by the lack of confidence in one's own abilities, disagreement with oneself, comprehension of the need to reassess oneself, uncertainty of life goals, lack of understanding of how to live, loss of the sense of the new, failure to keep pace with life, etc. The professional identity crisis can be said to be a situation of the "impossibility" to implement the internal career plan in the actual situation of professional development.

Our empirical study of the semantic content of the professional identity crisis, as well as the peculiarities of the experience thereof allowed us to specify the content of the professional identity crisis. In particular, we noted that the professional identity crisis experience by teachers is accompanied by the decreasing levels of meaning of the future and of satisfaction with past. Teachers experiencing a professional identity crisis feel the inability to control one's own life events and disbelief in their own power. These results are confirmed by the data of the contentanalysis of the phenomenological questionnaires.

\section{Materials and Methods}

\subsection{Research methods}

The following methods have been used for the research: theoretical (analysis, comparison); empirical (phenomenological questionnaire, testing); methods of mathematical statistics (descriptive statistics, comparative Mann-Whitney U test).

\subsection{Stages of research}

The research was carried out in 3 stages:

The first stage of the research included theoretical analysis of literature sources on the problem of the content of the professional identity crisis, on the disclosure of the characteristics of crisis experience. The content of semi-structured phenomenological interview was developed, a psychological diagnostic toolkit was selected for the diagnostics of the semantic context of the professional crisis.

At the second stage of the research empirical data was collected.

The third stage of the research included content analysis of self-reports of teachers, descriptive and comparative mathematical analyses of data.

The experimental sites of the research were comprehensive secondary educational organizations of the Sverdlovsk region of the Russian Federation.

\section{Results and discussion}

\subsection{Information about the experimental research work}


To test the hypothesis that the teachers experiencing a professional crisis undergo changes in the sense sphere of the personality (in particular, in life meaning orientations), an empirical study was conducted with the participation of teachers of comprehensive secondary schools of Ekaterinburg and the Sverdlovsk region. The median age of the participants is 36 years, work experience is 15 years. All the respondents have pedagogical education. The study involved 125 people in total. The group of teachers experiencing a crisis included 38 people. The rest of the teachers (87 people) made up the control group.

To get the empirical material the following tests were applied:

1. Life Meaning Orientations Test (LMO) by Leontiev (an adapted version of the Purpose-in-Life Test, PIL by J. Crumbaugh and L. Maholick). The methodology is aimed at studying life meaning comprehension. It makes it possible to identify the peculiarities of life meaning orientations of the individual (purpose in life, life richness and satisfaction with self-fulfilment), which correspond, respectively, to the aim (the future), the process (the present) and the result (the past). In addition, the methodology makes it possible to describe the locus of control - Self, reflecting the perception of oneself as a strong personality with sufficient freedom of choice, and locus of control - life, reflecting confidence in one's own ability to exercise such control (Self-image), to be free to take decisions and implement them.

2. The author's phenomenological questionnaire "Professional identity crisis experience", developed on the basis of the phenomenological methodology. The questions of the questionnaire covered several aspects of professional identity crisis experience by teachers: "general view of life and experiences prior to professional crisis development", "experiences accompanying the professional identity crisis", "value- and sense-focused field transformation", "overcoming the professional crisis. The interview was conducted with the aim of forming a group of teachers experiencing a professional identity crisis.

\subsection{The results of the experimental research}

The first purpose of the analysis of the empirical research results was the selection of a group of teachers experiencing a professional identity crisis. To this effect, the teachers' self-reports were analyzed. Teachers were included in the group experiencing a professional identity crisis on the following grounds: the teachers' selfassessment of the situation of professional activities as a crisis one or an uncritical one; the general emotional background of the self-report; the nature of evaluating professional activities; the nature of evaluating oneself as a professional. All in all the group of teachers experiencing a professional identity crisis included 38 people.

The second purpose of the analysis of the empirical research results implied the description of the sense sphere of teachers (life meaning experiences) undergoing a professional identity crisis.

To define the semantic context of the professional identity crisis we compared the results of the life meaning orientations test held in two different groups of teachers: teachers experiencing a professional identity crisis and teachers not experiencing such a crisis.

In general it should be noted that teachers experiencing a professional identity crisis show lower values in all indicators of life meaning orientations.

Though the sample on the whole showed median values of life meaning orientations, the values indicated by teachers experiencing a crisis tend to decline to the bottom border of the median level of these values. These preliminary results confirm the hypothesis that the professional crisis affects the sense sphere of the individual and starts the processes of its transformation.

To get more significant results we made a comparison between two independent samples using the Mann-Whitney nonparametric test (Mann-Whitney U

XLinguae, Volume 10, Issue 4, October 2017, ISSN 1337-8384, eISSN 2453-711X 
test). Table 1 presents significant differences in the parameters of life meaning orientations and value spheres in different groups of teachers.

Table 1: The results of the comparative analysis of the life meaning orientations parameters of different groups of teachers

\begin{tabular}{|c|c|c|c|c|}
\hline $\begin{array}{l}\text { Parameters of life } \\
\text { meaning } \\
\text { orientations }\end{array}$ & $\begin{array}{l}\text { Groups of } \\
\text { teachers } \\
(1 \quad-\quad \text { in } \\
\text { crisis, } \\
2 \\
\text { outofcrisis })\end{array}$ & $\begin{array}{l}\text { Averageran } \\
\mathbf{k}\end{array}$ & $\begin{array}{l}\text { Mann- } \\
\text { Whitney U } \\
\text { test } \\
\text { statistics }\end{array}$ & $\begin{array}{l}\text { Significance } \\
\text { level (p) }\end{array}$ \\
\hline \multirow{2}{*}{ Purposeinlife } & 1.00 & 41.86 & \multirow{2}{*}{$849.50^{*}$} & \multirow{2}{*}{0.00} \\
\hline & 2.00 & 72.24 & & \\
\hline \multirow{2}{*}{ Processoflife } & 1.00 & 54.59 & \multirow{2}{*}{1333.50} & \multirow{2}{*}{0.09} \\
\hline & 2.00 & 66.67 & & \\
\hline \multirow{2}{*}{ Effectivenessoflife } & 1.00 & 47.92 & \multirow{2}{*}{$1080.0^{*}$} & \multirow{2}{*}{0.00} \\
\hline & 2.00 & 69.59 & & \\
\hline \multirow{2}{*}{$\begin{array}{ll}\text { Locusofcontrol - } \\
\text { Self }\end{array}$} & 1.00 & 42.99 & \multirow{2}{*}{$892.50^{*}$} & \multirow{2}{*}{0.00} \\
\hline & 2.00 & 71.74 & & \\
\hline \multirow{2}{*}{$\begin{array}{l}\text { Locusofcontrol - } \\
\text { Life }\end{array}$} & 1.00 & 51.11 & \multirow{2}{*}{$1201.00 *$} & \multirow{2}{*}{0.02} \\
\hline & 2.00 & 68.20 & & \\
\hline \multirow{2}{*}{$\begin{array}{l}\text { Generalcomprehe } \\
\text { nsionoflife }\end{array}$} & 1.00 & 54.61 & \multirow{2}{*}{1334.00} & \multirow{2}{*}{0.09} \\
\hline & 2.00 & 66.67 & & \\
\hline
\end{tabular}

* significant differences in the degree of expression of the parameters of life meaning orientations of teachers of different groups

Here is the analysis of the results.

The comparative analysis shows that at the significance level $\mathrm{p} \leq 0.05$ there are differences on the following scales of the life meaning orientations test: "Purpose in life", "Effectiveness of life or satisfaction with self-realization," "Locus of control Self (I am the master of life)", "Locus of control - life or controllability of life". Teachers experiencing a professional crisis are characterized by lower indicators of these parameters. Here is a qualitative analysis of the results.

The scale "Purpose in life" characterizes the presence or absence of future objectives in the life of a teacher that provide life with meaning, direction and time perspective. The decreasing indicators of this scale $(\mathrm{X}$ mean $=34.34)$ proves that it typical of a teacher experiencing a professional crisis to live for today without planning the future as it is obscure and the professional prospects are not clear.

The indicators of the scale "The effectiveness of life or satisfaction with self-realization" (X mean $=25.08$ ) reflect the evaluation of the previous segment of life, the feeling of how effective and meaningful it was. As it is typical of teachers experiencing a crisis to have low indicators in this scale, we can state that the teachers are mainly dissatisfied with the previous part of their lives. This is probably due to the fact that in a crisis situation teachers feel the need to revise their own achievements, to reflect on their own experience and capabilities. Besides, the dissatisfaction with the past may be due to the feeling that their professional knowledge and skills cannot ensure the fulfillment of the tasks declared by the social and professional environment in the current context of professional activities.

The scale "Locus of control - Self (I am the master of life)" $(\mathrm{X}$ mean = 24.34) characterizes the teachers' perception of themselves as strong personalities having a sufficient freedom of choice to build their lives according to their purposes and life meaning perceptions. As the results of the test show that the teachers have low indicators in this scale it is possible to say that teachers experiencing a 
professional identity crisis are characterized by disbelief in their own power and inability to control the events in their own lives.

The scale "Locus of control - life or controllability of life" also showed a statistically significant decrease of the level $(\mathrm{X}$ mean $=30.45)$. This scale testifies to the conviction that a person can control his/her own life, make decisions freely and implement them. Teachers experiencing a professional identity crisis are characterized to a greater degree by the conviction that a person's life is not subject to conscious control, that freedom of choice is an illusion and that it is useless to think ahead.

It is of interest to note the fact that the general level of life comprehension and its emotional intensity (the scale "Process of life") does not show statistically significant differences between the groups of teachers. Life as a whole is perceived as interesting and fulfilled while the situation of the professional identity crisis changes only some of the parameters of life meaning orientations significant for the teaching activity.

To describe the content of the process of of the teachers' experience of a professional identity crisis we made a content analysis of the teachers' phenomenological questionnaires. When developing a phenomenological questionnaire on the basis of theoretical analysis of the research made by different scholars, we established content analytical categories, revealing the essence of the experience process (Sadovnikova, Sergeeva, Suraeva, Kuzmina, 2016). Among them:

Category A - general view of life prior to the professional identity crisis.

A1 - image of profession;

A11 - social significance of the profession;

A12 - interest in the activity;

A13 - creative self-actualization possibility;

A14 - professional prospect availability;

A2 - image of Self in the profession;

A21 - proactive attitude;

A22 - subjectivity, self-confidence;

A23 - self-identification with the profession;

A24 - self as viewed by others;

A3 - general emotional background;

A31 - exhilarated emotional background;

A32 - calm, smooth emotional background.

Category $B-$ general view of life within the professional identity crisis.

B1 - image of profession within the period of crisis;

B11 - low social significance of the profession;

B12 - lack of interest in the activity;

B13 - routine nature of the activity;

B14 - lack of professional prospect;

B2 - image of Self within the period of crisis;

B21 - loss of control of activity and professional situations;

B22 - development arrest;

B23 - professional identity loss;

B24 - negative external evaluations of the activity;

B25 - self-esteem drop.

Category $\mathrm{C}$-crisis experience.

$\mathrm{C} 1$ - emotional sufferings,

C11 - anxiety, fear;

C12 - anger, irritation;

C13 - sadness, emptiness;

C14 - desperation, hopelessness,

C15 - stress,

XLinguae, Volume 10, Issue 4, October 2017, ISSN 1337-8384, eISSN 2453-711X 
C2 - value and sense sphere transformation;

$\mathrm{C} 21$ - life sphere hierarchy change;

$\mathrm{C} 22$ - change of sense content of work;

$\mathrm{C} 3$ - reflection;

C31 - internal world reflection;

$\mathrm{C} 32$ - activity content reflection;

C33 - social environment reflection.

Category D - crisis overcoming activity.

D1 - the use of social resources;

D2 - personality resources actualization;

D3 - hobbies and interests;

D4 - change of the workplace;

D5 - change of profession;

D6 - change of the type of activity.

All in all in the analysis of the responses of the subjects we identified 686 statements describing the content of the experience of teachers in a professional identity crisis. Within this article we will focus on the content of the experiences revealing the features of the professional identity crisis.

The analysis of the responses of the teachers describing the experience of a professional crisis (category $B-$ general view of life within the professional identity crisis) suggests that in a crisis situation teachers begin to perceive distinctly the evaluation of their activities. Many subjects noted the manifestation of negative external evaluations: "the fear of condemnation", "I felt myself a black sheep", "I can't be good", "the attitude of the colleagues as to a competitor," "gossip, pressure", "misunderstanding on the part of the superiors", "not being taken for a colleague", etc. (subcategory B24, 21\%). The pedagogical activity involves constant feedback from the students, the parents, the colleagues and the profession as a whole.

Another frequent category in the responses of the subjects was the category "loss of control of activity and professional situations" (subcategory B21, 20\%): "my fingers are all thumbs", "emptiness, no new ideas", "I will never succeed in the way I would like to", "I can't decide", etc. The manifestations of subjectivity and selfconfidence characteristic of the perception of a professional situation prior to the crisis are lost during the crisis, which is one of the leading sources of experience along with negative external evaluations.

Unclear time frames of professional prospects or their absence (subcategory $\mathrm{B} 14,12 \%$ ), and as a result, actualization of the need to choose the further professional life scenario were reflected in such responses as: "do I need this profession", "will it be interesting in the future", "I would like to change my job", "the professional future is dismal", "the professional future - everything is as usual and will only get worse", etc. In the pre-crisis period, the image of the profession included both professional plans, and opportunities for self-realization. Unclear career prospects are one of the attributes of the professional identity crisis experience.

It is also worth noting that the subjects pointed out lack of interest in the activity (subcategory B12,17\%) and routine nature of the activity (subcategory B13, $14 \%$ ) in the professional crisis period.

The comparison of the view of life of the teachers before and during the experience of the professional identity crisis makes it possible to draw an intermediate conclusion that the image of the profession and the professional "Self" develop according to the dichotomic principle. The teachers single out the same key points, but the crisis situation changes the character of the assessment of the situation drastically from positive to negative. In the description of the crisis teachers avoid neutral judgments, they incline towards polar assessments. Perhaps the polarization of professional situation assessments is one of the mechanisms of the perception of the professional identity crisis by teachers that are at the initial stages of 
professionalization and experience a crisis of professional expectations. Categorical assessments, division into "black" and "white" may also indirectly indicate the insufficient level of self-actualization in the profession, the immaturity of the professional mindset.

The next purpose of the analysis was to determine the correlation of the features revealing the essence of the professional crisis experience (category $C$ crisis experience).

The main aspect of the experience is associated with the change of the semantic context of work (subcategoryC22, 21\%). Many teachers pointed out: "it seemed to me that everything was forgotten", "I stopped taking home notebooks for checking", "I can't understand if I need it", "I have become less responsive to the demands of the parents", "now I use my willpower to make myself go, I perform my professional duties by habit, automatically", "it became meaningful to protect my child from what is now going on in the kindergarten", "I am very disappointed by the education system", "I began to look at my activity with different eyes", etc.

For many teachers the experience of a professional crisis is accompanied by the reflection on the content of professional activity (subcategory C32, 18\%), followed by the reflection on the inner world (subcategory C31, 13\%) and on the social environment (subcategory C33, 13\%).

If we analyze the emotional context of the experiences, it can be noted that the dominant emotions were "desperation and hopelessness" (subcategory C14, 7\%). The teachers pointed out: "there was inner emptiness", "emptiness", "burnout was felt", "sense of hopelessness, that nothing can be changed", "the desire to leave my job, to give up everything", "humility", etc.

In general, the results as to category B conform with the initial theoretical model of crisis experience. It is of interest to note the fact that negative emotional experiences that make up the general background of the crisis development are not so often pointed out by the teachers as the sense and value sphere transformation and reflection. This can be explained by the fact that teachers' emotional self-regulation is professionally developed and the reflexive and the value aspects of the experience come to the fore as mechanisms of a higher level.

An important part of the analysis was the analysis of the correlation of the features revealing the professional crisis overcoming process (category D - crisis overcoming activity). The largest number of responses was given in subcategory D2 personal resources actualization. The teachers pointed out that to resolve the professional crisis they needed "patience and calm", "I understood that if you can't change the situation, change the attitude towards it", "self-confidence", "optimism", "confidence in my knowledge and my power", "stress tolerance", "confidence that the crisis will be over, motivation", etc.

Social resources were of considerable importance in overcoming the professional crisis (subcategory D3, 26\%). The self-reports of the subjects included such responses as: "I interacted with other professionals", "I appealed to the family, senior teachers, we talked it over, clarified the situation", "I appealed to a person who knows very well the specificity of the work", "I appealed to the leaders, who supported me with good words".

Personal resources actualization and appeal for social support are, in our view, quite a constructive way of overcoming the crisis, since it allows the teacher to retain his/her professional status and stay in the profession.

Social contacts are a resource for coping with loss-of-meaning situations. Communication with other people, joining them for cooperative activities serve as a catalyst for rethinking the negative life experiences, helps reconstruct or compensate for the lost meaning.

XLinguae, Volume 10, Issue 4, October 2017, ISSN 1337-8384, eISSN 2453-711X 
Another constructive option for coping with a crisis situation, in our view, is subcategory D6 - change of the type of activity (11\%). This category includes such responses as: "at that time I applied to the university to get higher education", "I realized that I must do something to cope with the crisis situation", "I was offered an interesting second job", "to change the activity", "I participate in contests and I win", etc.

So, the results of the empirical study allowed us to reveal the semantic context of the professional identity crisis and the specificity of experiencing it.

\section{Conclusion}

This article presents the results of the study of the content of the professional identity crisis. The main conclusion can be considered to be the fact that the situation of the professional identity crisis actualizes the experience process in the consciousness of the individual. The generalization of the responses of the teachers made it possible to state that in a crisis situation the teachers begin to perceive distinctly the evaluation of their activities, feel the lack of control over the activities and professional situations. The manifestations of subjectivity and self-confidence characteristic of the perception of a professional situation prior to the crisis are lost during the crisis, which is one of the leading sources of experience along with negative external evaluations.

Unclear time frames of career prospects, or their absence, and as a result, actualization of the need to choose the further professional life scenario make up one more aspect of the professional identity crisis experience by teachers. The subjects noted lack of interest in the activity and its routine nature in the professional crisis period.

In the course of the study it was noted that the professional identity crisis of the teacher is characterized by the decline in the degree of expression of some parameters of life meaning orientations: purpose in life, effectiveness of life (satisfaction with self-realization), locus of control - Self, locus of control - life. The professional identity crisis is characterized by the pronounced dissatisfaction with the past, the feeling of uselessness of the phase that has passed and failure in selfrealization. The feeling of inability to influence the course of one's own life, as well as lack of confidence in the ability in principle to make one's own choice in life - these are also indicators of the professional identity crisis

In the course of the study it was found out that the main aspect of the teachers' professional identity crisis experience is linked to the change of the semantic context of their work. For many teachers the professional crisis experience is accompanied by the reflection on the content of the professional activity, then it actualizes the reflection on the inner world and the social environment.

The results brought out in this paper complement the idea of the essence of the professional identity crisis, but they are far from being end results. They confirm the hypothesis about the semantic nature of the professional identity crisis.

The findings enrich the idea of the experience essence. The obvious novelty of the research is in revealing the semantic features of the teachers' professional identity crisis experience.

The results of this research can be the basis for designing the system of psychological and pedagogical support of teachers' professional development and activities.

\section{Acknowledgments}

The research is performed thanks to the support of the Russian Humanitarian Scientific Foundation within the framework of scientific and research project "Psychological mechanisms of professional identity crisis experience by teachers", project No.16-36-01031. 


\section{Bibliograpic references}

ADLER, A. 1926. Individual psychology as a path to the knowledge and selfknowledge of man. Available online: http://lib.ru/PSIHO/ADLER/Adler-3.txt

ANTSYFEROVA, L.I. 1981. About psychology of personality as a developing system. Psychology of personality formation and development. Moscow. Nauka. 364 p.

ASSAGIOLI, R. 2007. Cognition of the Higher Self and psychological disturbances. Psychosynthesis and other integrative psychotherapy techniques. Moscow. Smysl. 298 p.

ASADULLIN, R.M. - FROLOV O.V. 2017. Crisis of pedagogical culture and some problems of the modern pedagogical thought. In: The Education and science journal, vol. 2, pp. 9-31. ISSN 1804-2473.

BENIN, V.L. - FROLOV, O.V. 2014. Socio-philosophical problems of the higher vocational education in the context of culture crisis. In: The Education and science journal, vol. 1, pp. 44-54. ISSN 1804-2473.

BÜHLER, C.H. 1933. Der menschliche Lebenslaufals Psychologisches Problem. Available online: https://www.e-periodica.ch/digbib/volumes?UID=sle-001

CAPLAN, G. 1964. Principles of preventive psychiatry. NewYork. Basis Books. $304 \mathrm{p}$.

GROF, S. - HALIFAX, J. 1996. Man in the face of death. Moscow. Transpersonal Institute Publ. 246 p.

FILLIP, S.H. - AYMANNS, P. 2010. Kritische Lebensereignisse und Lebenskrisen. VomUmgangmit den Schattenseiten des Lebens. Stuttgart. Kohlhammer. 448 p

FONAREV, A.R. 1997. Forms of personality development in the process of professionalization. In: Issues of psychology, vol. 2, pp. 20-32. ISSN: 1464-066X.

FREUD, S. 1917. Introduction to psychoanalysis: lectures. Available online: http://modernlib.ru/books/freyd_zigmund/vve-denie_v_psihoanaliz_lekcii/read ERIKSON, E. 1963. Childhood and society. New York: Norton. 447 p.

JAMES, R.K. - GILLILAND, B.E. 2005. Crisis Intervention Strategies. Belmont. Wadsworth. 720 p.

KE, Z. - BORAKOVA, N.U. - VALIULlinA, G.V. 2017. Peculiarities of Psychological Competence Formation of University Teachers in Inclusive Educational Environment. In: EURASIA Journal of Mathematics, Science and Technology Education, vol. 13, n. 8, pp. 4701-4713.

KHRULYOVA, A.A. - SAKHIEVA, R.G. 2017. Forming of Informational Culture as a Necessary Condition of the Level Raising of Higher Education. In: Man In India, vol. 97, n. 15, pp. 211-225. ISSN: 00251569.

KLIMOV, E.A. 1996. Psychology of professional self-determination. Rostov-on-Don. Feniks. 509 p.

KONG Y. - KAYUMOVA, L.R. - ZAKIROVA, V.G. 2017. Simulation Technologies in Preparing Teachers to Deal with Risks. In: EURASIA Journal of Mathematics, Science and Technology Education, vol. 13, n. 8, pp. 4753-4763. ISSN: $13058215,13058223$.

LEVINA, E.Y. - MASALIMOVA, A.R. - KRYUKOVA, N.I. - GREBENNIKOV, V.V. - MARCHUK, N.N. - SHIREV, D.A. - RENGLIKH, K.A. - SHAGIEVA, R.V. 2017. Structure and Content of e-Learning Information Environment Based on Geo-Information Technologies. In: EURASIA Journal of Mathematics, Science and Technology Education, vol. 13, n. 8, pp. 5019-5031. ISSN: 13058215, 13058223.

LIEVEGOED, B. 1994. Crises of life - chances of life. Kaluga. Dukhovnoe poznanie Publ. 224 p. 
LINDEMANN, E. 1944. Symptomatology and management of acute grief. In: American Journal of Psychiatry, vol. 101, pp. 141-148. ISSN 0002-953X.

MALKINA-PYKH, I.G. 2004. Age crises: handbook of a practical psychologist. Moscow. Eksmo. 554 p.

MARKOVA, A.K. 1996. Psychology of professionalism. Moscow. Znanie. 312 p.

MARTSINKOVSKAYA, T.D. 2002. Heavy experience as a form of psychological crisis. Anthology of heavy experiences: socio-psychological assistance. Moscow. Moscow State Pedagogical University. 336 p.

MASALIMOVA, A.R. - LEVINA, E.Y. - PLATONOVA, R.I. - YAKUBENKO, K.Yu. - MAMITOVA, N.V. - ARZUMANOVA, L.L. - GREBENNIKOV, V.V. MARCHUK, N.N. 2017. Cognitive Simulation as Integrated Innovative Technology in Teaching of Social and Humanitarian Disciplines. In: EURASIA Journal of Mathematics, Science and Technology Education, vol. 13, n. 8, pp. 4915-4928. ISSN: 13058215, 13058223.

MASLOW, A. 1971. The Farther Reaches of Human Nature. Available online: http://maslow.com/contents/fartherreaches.htm

MITINA, L.M. 2002. Psychology of competitive personality development. Moscow. Moscow Psychologic-Social Institute. 400 p.

MOGILEVKIN, E.A. 2007. Career development: diagnostics, technology, training. Saint-Petersburg. Rech. 336 p.

POVARENKOV, Y.P. 2002. Psychological content of professional development of a person. Moscow. University of Russian Academy of Education Publ. 160 p.

PROKHOROV, A.O. 2004. Theoretical and methodological aspects of the problem of unbalanced mental states. Psychology of states. Moscow. PER SE. 608 p.

PROKHOROV, A.O. - CHERNOV, A.V. - YUSUPOV, M.G. 2017. Dynamics of Mental States' Representations in the Conditions of Experimental Influence. In: Eurasian Journal of Analytical Chemistry, vol. 12, n. A Multidisciplinary Approach to science 5b, pp. 579-590. e-ISSN: 1306-3057.

PRYAZHNIKOV, N.S., PRYAZHNIKOVA, E.YU. 2005. Psychology of labour and human dignity. Moscow. Academia publ. 480 p.

RENSH, M.A. - KOSYAKOVA, I.V. - AGAFONOVA, A.N. 2016. Research into the Specific Aspects of Internal Conflict Displays in the Course of Professional Identification. In: International Journal of Environmental and Science Education, vol. 11(14), pp. 7079-7090. ISSN: 1306-3065

OLSON, A. 2013. The theory of Self-actualization: mental illness, creative and art. Available online: https: www. psychologytoday.com/blog/theory-andpsychopatology/201308/the-theory-self-actualization

SADOVNIKOVA, N.O. 2016. Professional identity crisis of teachers: content and main features. In: Scientific dialogue,vol. 11(59), pp. 400-411. ISSN 2414-9918.

SADOVNIKOVA, N.O. 2009. Value-semantic features of non-standard crisis of career. In: The Education and science journal, vol. 6(63), pp. 89-97. ISSN 2227-7102.

SADOVNIKOVA, N.O. 2014. Teachers' overcoming barriers to professional development: activity approach. In: Modern problems of science and education, vol. 5, pp. 659-667. ISSN 2070-7428.

SADOVNIKOVA, N.O. - SERGEEVA, T.B. - SURAEVA, M.O. - KUZMINA, O.Y. 2016. Phenomenological Analysis of Professional Identity Crisis Experience by Teachers. In: International Journal of Environmental and Science Education, vol. 11(14), pp. 6898-6912. ISSN: 1306-3065.

SHEEHY, G. 1999. Age crises-stages of personal growth. Saint-Petersburg. Yuventa. $372 \mathrm{p}$.

SOLDATOVA, E.L. 2007. Structure and dynamics of the standard crisis of transition to adulthood. Chelyabinsk. South Ural State University Publ. 267 p. 
SYMANYUK, E.E. - DEVIATOVSKAJA, I.V. 2015. Life-long education as a resource to overcome the psychological barriers in the process of professional development of the individual. In: The Education and science journal, vol. 1, n. 1, pp. 80-92. ISSN 2227-7102.

ULICH, D. - HAUSSER, K. - MAYRING, PH. - STREHMEL, P. - KANDLER, M. - DEGENHARDT, B. 1985. Psychologie der Krisenbewaeltigung eine Laengsschnittuntersuchung mit arbeitslosen Lehrern. Weinheim. Beltz. 244 p.

VALEEVA, R.A. - GAFUROV, I.R. 2017. Initial teacher education in Russia: connecting theory, practice and research. In: European Journal of Teacher Education, vol. 40, n. 3, pp. 342-360. ISSN: 1469-5928.

VASILYUK, F.E. 1984. Psychology of experience. Moscow. Moscow State University. $200 \mathrm{p}$.

VYGOTSKY L.S. 1927. A biogenetic law in psychology and pedagogy. In: Great Soviet encyclopedia, vol. 6, pp. 275-279. ISBN: 5-85270-324-9.

YURIEVA, L.N. 1998. Crisis states. Dnepropetrovsk. Art-Press.156 p.

ZEER, E.F. 2013. Controversial Aspects of Innovative Trends of Vocational Pedagogic Education. In: The Education and science journal, vol. 5, pp. 67-83. ISSN 2227-7102.

ZEER, E.F. 2009. Psychology of professional development. Moscow. Academia. 240 p.

ZEER, E.F. - SYMANYUK, E.E. 2005. Professional orientology of personality: Training manual. Ekaterinburg. Russian State Vocational Pedagogical University Publ. 186 p.

ZHELTUKHINA, M.R. - VIKULOVA, L.G. - MIKHAYLOVA, S.V. BORBOTKO, L.A. - MASALIMOVA, A.R. 2017. Communicative theatre space in the linguistic and pragmatic paradigm. In: XLinguae, vol. 10, n. 2, pp. 85-100. ISSN $1337-8384$.

Words: 7906

Characters: 53096 (29,5 standard pages)

Assoc. Prof. Nadezhda O. Sadovnikova, PhD

Assoc. Prof. Tamara B. Sergeeva, PhD

Assoc. Prof. Svetlana S. Kotova, PhD

Assoc. Prof. Irina V. Deviatovskaja, PhD

Institute of Psychological and Pedagogical Education

Russian State Vocational Pedagogical University,

Mashinostroiteley Street 11

620012 Ekaterinburg

Russia

nosadovnikova@gmail.com

tamara.2005@mail.ru

89193885388@mail.ru

irina-vlad2007@rambler.ru

Alexander A. Shashmurin

Institute of Psychological and Pedagogical Education

Russian State Vocational Pedagogical University,

Mashinostroiteley Street 11

620012 Ekaterinburg

Russia

alexandershashmurin@mail.ru

XLinguae, Volume 10, Issue 4, October 2017, ISSN 1337-8384, eISSN 2453-711X 